\title{
Do not miss secondary syphilis: examine the palms and soles
}

\author{
Yasmin Hughes
}

Western Sydney Sexual Health Centre, Western Sydney Local Health District, Parramatta, NSW, Australia

\section{Correspondence to} Dr Yasmin Hughes; yasminhughes83@outlook.com

Accepted 26 October 2020

\section{DESCRIPTION}

A 30 year old gentleman from Papua New Guinea with a history of intravenous drug use and previous imprisonment presented with a 2 -week history of a non-pruritic scrotal rash. He denied any associated genitourinary, dermatological or systemic symptoms. He was an otherwise well gentleman with no significant medical history and took no regular medications. Sexual history revealed an episode of unprotected anal sex with a casual male partner 5 months prior to his presentation and four male partners in the preceding 12 months.

Examination demonstrated multiple grey papules of approximately $1 \mathrm{~mm}$ diameter symmetrically distributed on the scrotum. Further thorough examination was conducted to exclude secondary syphilis; regular, round brown papules were identified on the trunk, back, palms of the hands and soles of the feet, which had not been noticed by the patient (figure 1). Oral examination demonstrated grey lesions overlying the soft and hard palate suspicious for mucous patches (figure 2). There was no associated lymphadenopathy or other concerning pathology noted.

The findings were suspicious of secondary syphilis, so oral and genital lesions were sampled for nucleic acid amplification testing (NAAT) of Treponema pallidum DNA. A screen for sexually transmitted infections including HIV and syphilis was conducted. Empirical treatment with intramuscular benzathine penicillin $(1.8 \mathrm{~g})$ was given and the patient was advised to abstain from sex for 1 week. Both NAAT and serological assays subsequently confirmed the diagnosis of secondary syphilis with a venereal disease reference laboratory titre of 1:64. At follow-up, 1 week later, the patient's symptoms had improved with treatment and partners from the preceding 6 months had been notified.
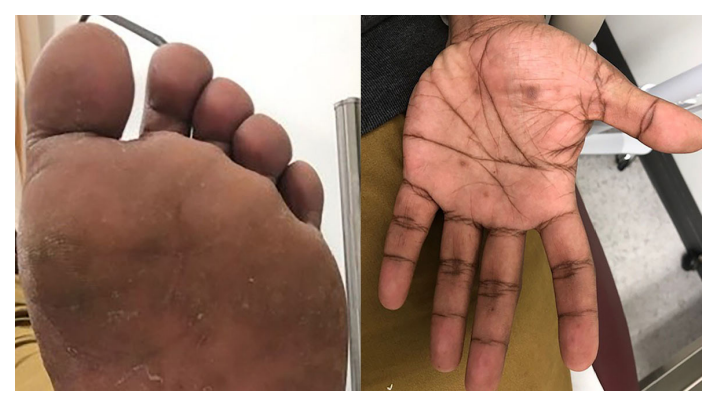

Figure 1 Lesions of secondary syphilis on the palm of the hand and the sole of the foot. Notice how subtle the lesions are; they may be overlooked unless specifically examined for.

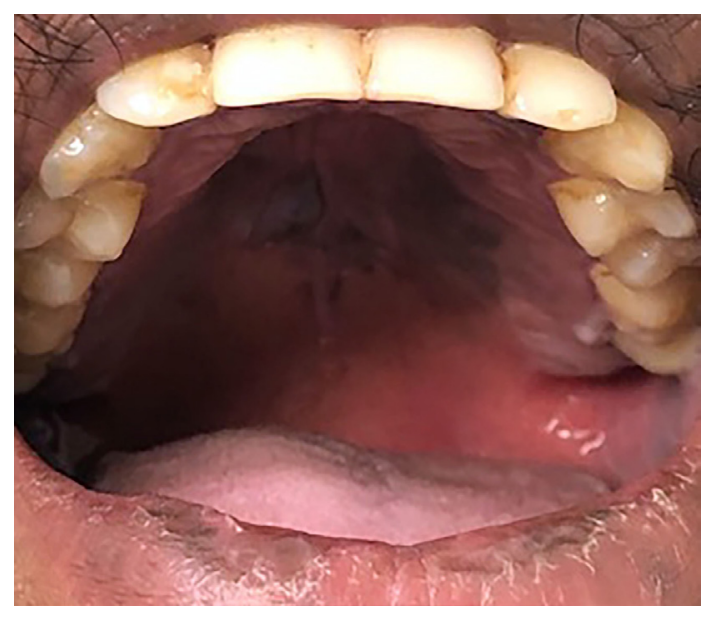

Figure 2 Mucous patches of the oral cavity; a feature of secondary syphilis. Mucous patches, condylomata lata and other dermatological features of syphilis are incredibly infectious; gloves should be worn during specimen collection and examination couches cleaned afterwards.

Syphilis, known as the 'great imitator', is caused by T. pallidum and is on the rise. ${ }^{1}$ Primary infection causes a, traditionally, painless, syphilitic chancre which heals within weeks and may go undetected by the patient. Haematogenous dissemination of T. pallidum occurring up to 6 months after initial infection results in secondary syphilis, which may prompt patients to seek medical attention. Dermatological manifestations of secondary syphilis can be non-specific and may present to practitioners working outside of sexual health. Condylomata lata are non-tender, moist, papules in the genital region which may be confused with genital warts. A maculopapular rash, present in up to $90 \%$

\section{Learning points}

The primary chancres of syphilis may go undetected by patients, delaying presentation until symptoms of secondary syphilis develop.

- Dermatological manifestations of secondary syphilis can be non-specific and may present to practitioners working outside of sexual health.

- Hallmark features of secondary syphilis include a maculopapular rash, typically affecting the palms and soles, mucous patches of the oral cavity and condylomata lata on the genital skin; examination of these areas is therefore key to clinching the diagnosis. 
of patients, may be subtle and easily confused with pityriasis rosea, infectious mononucleosis, HIV seroconversion or drug reaction. $^{23}$ One distinguishing feature of the rash in secondary syphilis is the involvement of the palms of the hands and soles of the feet as shown in figure 1. Mucous patches of the oral cavity are a hallmark feature of secondary syphilis and can be subtle (figure 2), being overlooked unless specifically examined for. Left untreated, secondary syphilis may lead to the complications of tertiary syphilis; ${ }^{1}$ therefore, a high index of suspicion coupled with a thorough dermatological assessment, including assessment of the palms, soles and oral cavity of patients presenting with genital lesions, is required to make the correct diagnosis.
Contributors YH planned, designed and conducted the research contributing to this paper. She is entirely responsible for the write up and revisions.

Funding The authors have not declared a specific grant for this research from any funding agency in the public, commercial or not-for-profit sectors.

Competing interests None declared.

Patient consent for publication Obtained

Provenance and peer review Not commissioned; externally peer reviewed.

\section{REFERENCES}

1 Bissessor M, Chen M. Syphilis, the great mimicker, is back. Aust Fam Physician 2009:38:384-7.

2 Baughn RE, Musher DM. Secondary syphilitic lesions. Clin Microbiol Rev 2005;18:205-16.

3 Baeten J, Celum CJong EC, Sanford CA, eds. The travel and tropical medicine manual. 4th edn. Philadelphia, PA, USA: Saunders/Elsevier, 2008.

Copyright 2020 BMJ Publishing Group. All rights reserved. For permission to reuse any of this content visit

https://www.bmi.com/company/products-services/rights-and-licensing/permissions/

BMJ Case Report Fellows may re-use this article for personal use and teaching without any further permission.

Become a Fellow of BMJ Case Reports today and you can:

- Submit as many cases as you like

- Enjoy fast sympathetic peer review and rapid publication of accepted articles

Access all the published articles

Re-use any of the published material for personal use and teaching without further permission

Customer Service

If you have any further queries about your subscription, please contact our customer services team on +44 (0) 2071111105 or via email at support@bmj.com.

Visit casereports.bmj.com for more articles like this and to become a Fellow 